\title{
Research on the Innovative Design of Multi-functional Shoe Cabinet
}

\author{
Wu Nai-qun, Shi Yao-jun* and Dai-ye \\ School of Mechanical \& Power Engineering, Harbin University of Science and \\ Technology, Heilongjiang Harbin 150080, China \\ wwwsyj@sina.com
}

\begin{abstract}
Through the analysis of current shoe cabinet market, aiming at some of the families that in needs of shoes cleaning, disinfection and storage, especially in areas of hot weather or frequently accompanied by rain and snow. The shoe cabinet was redestgned, to meet the needs of consumers on the shoes cleaning, sanitary and storage. This paper is mainly based on ergonomics principle and humanized design,concept, designing and researching from the aspects of function, material, color and institutions of hoe cabinet, to design multi-functional shoe that sets disinfection and storage $\hat{a}_{\mathbf{5}}$ a whole and give a new design concept for shoe cabinet which makes user to enjoy the multi-functional shoe cabinet with hygiene and soft at the same time feeling the beaut and enjoy what design brings to our life.
\end{abstract}

Keywords: multi-functional; shoe cabinet design; research.

\section{Introduction}

The improvement of the quality of life makes people pay more and more attention to their own side of the details of life. Also, people are looking for more healthy, safe and environmental products tomprove the quality of life. However, the shoes cleaning and hygiene have not been emphasized by people. Shoes are not disposable products, but the necessities of life which can contimue to use a period of time. Wet sludge or foot sweat, etc., will affect hoes health and users health. A clean and disinfection household shoe cabinet can store shoes, meanwhile let us enjoy our life better.

The form and function of hoe cabinet on current market are very simple, because in the eyes of most people the role of shoe cabinet is just for storing shoes. Moreover, people are generally only concerned about the health of the socks, replacing and cleaning socks daily. But they will Ignore the hygiene of shoes, because shoes are difficult to clean and disinfect. Shoes are easy to breed a lot of bacteria, causing a variety of bacteria including infection of beri-beri, tinea pedis, etc., and then becoming a medium for the spread of germs. Foo sweat will make the shoes in a warm and humid state when people in shoes, which provides a suitable environment for bacteria's growth. The health problem of shoes is a-blind area that people don't pay attention to. If combine the function of drying and sterilizing with the shoe cabinet can store shoes at the same time preventing foot diseases, improving the people's living standards.

Multi-functional shoe cabinet mainly combines the function of disinfection and storage. Disinfection sterilization mainly uses ozone sterilization technology. Ozone sterilization is the use of ozone in the oxidation of oxygen atoms to carry out sterilization; it can effectively destroy the structure of the microbial membrane, so as to achieve the effect of cleaning and sterilization.

The innovative design of multi-functional shoe cabinet is mainly embodied in the following aspects. 


\section{Function and Structure}

\subsection{Function Principle}

The main function of multi-functional shoe cabinet is disinfecting, sterilizing and deodorizing the shoes, and in addition to dry the wet shoes.

Disinfection mainly relies on ozone sterilization to achieve the requirements of sterilization.

Ozone which is a light blue gas with special smell at room temperature is allotrope of oxygen. Ozone's English name is "Ozone". Ozone can sterilize quickly, safely and effectively, and besides it has the function of deodorization ${ }^{[1]}$. The characteristic data of ozone is as shown in Table 1.

Table 1.Typical Physical Properties Data of Ozone

\begin{tabular}{c|c|c|c|c}
\hline $\begin{array}{c}\text { Density } \\
\left(0{ }^{\circ} \mathrm{C} 0.1 \mathrm{MPa}\right) \mathrm{g} / \mathrm{L}\end{array}$ & $\begin{array}{c}\text { Boiling } \\
\text { point }\left({ }^{\circ} \mathrm{C}\right)\end{array}$ & Melting point $\left({ }^{\circ} \mathrm{C}\right)$ & $\begin{array}{c}\text { Molecular } \\
\text { weight }\end{array}$ & Water solubility $\left(\mathrm{H}_{2} \mathrm{O} / \mathrm{L}\right)$ \\
\hline 2.14 & -111 & 29 & 47.9982 & 0.494 \\
\hline
\end{tabular}

Ozone has strong oxidation, and its high ozone concentration is harmful to human body. The starting point for the concentration of ozone toxicity is $0.3 \mathrm{ppm}$, while the concentration of ozone in the air people can sniff is $0.02 \sim 0.04 \mathrm{ppm}$. According to the results of the experiment on ozone for lung toxicity, $1.5 \sim 2.0 \mathrm{ppm}$ is considered to be the cap on the allowable concentration of ozone. Ministry of Health provides the maximum allowable concentration of ozone is $0.3 \mathrm{mg}\left(\mathrm{m}^{3}\right)(0.15 \mathrm{ppm})$.

Air application concentration

If ozone is used to deodorize and sterilize, it requires low concentrations of ozone, such as $0.25 \mathrm{ppm}\left(0.5 \mathrm{mg} / \mathrm{m}^{3}\right)$, while if ozone is used to disinfect the surface of an article (killing bacteria and chemical pollution), it is gequired to increase the concentration of ozone several times.

Ozone Generator

There are three main Rinds of methods of the occurrence of ozone:

(1)High voltage discharge type

(2)UV irradiation type

(3)Electrolytic type

The high voltage dischange type is most widely used, because the technology of this method has been very mature, consumption of electronic components is relatively small, and working conditions are stable and safe. Its working principle is shown in Figure 1.

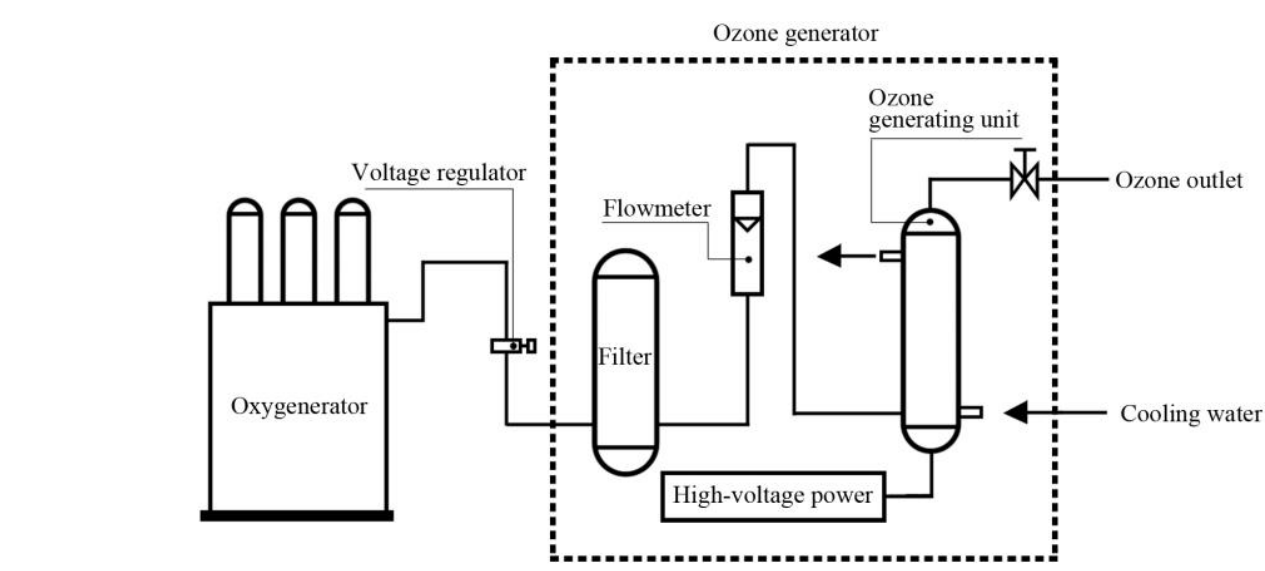

Figure 1. Working Principle of High Voltage Discharge Ozone Generator 
Among them, the discharge tube in the generator is the core technology and equipment of the production of ozone with high voltage discharge. The working condition of the discharge tube also directly affects the safety and manufacturing efficiency of the whole device. Discharge tube using micro-gap dielectric barrier discharge design, can greatly improve the safety of the device, and increase the efficiency of ozone production. This technology has been widely used in the production of ozone.

The dryer of versatile shoe cabinet mainly relies on heating equipment to evaporate moisture vapor inside the shoe. However, the choice of dryer heating element is very important, if the power of heater is too large, it will damage the shoes, but the power is too small, which cannot guarantee the drying time. Most common heating device in people's daily life is PTC heater. PTC heater and its working principle are shown in Figure 2.

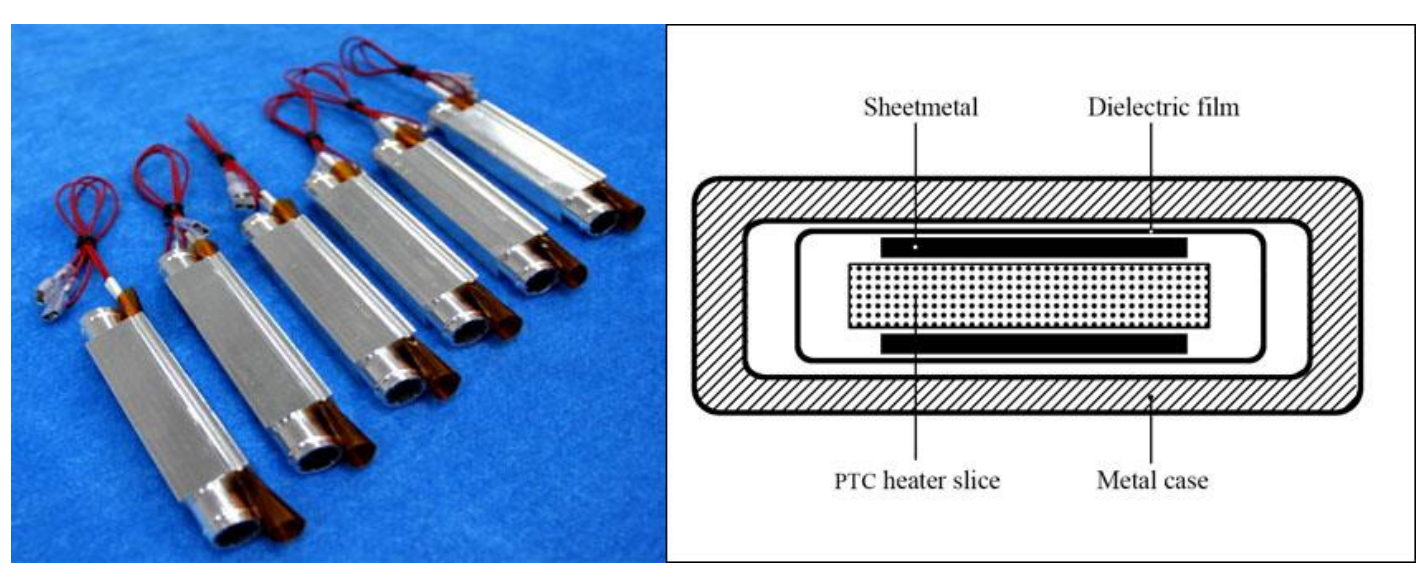

Figure 2. PTCHeater and Its Working Principle

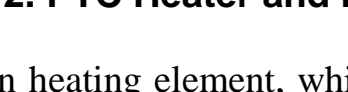

PTC heater is a common heating element, which now is widely used in floor heating, foot bath temperature heater, heater, incubator and so on many products closely related to people's life. PTC heater power is small, the constant temperature performance is good, and is energy efficient and environmentally friendly. This kind of heating way to the shoe basically has no harm ${ }^{[2]}$.

The main technical parameters of the PTC element used in the electric heater are shown in Table 2.

Table 2. Characteristics of PTC Element R25

\begin{tabular}{c|c|c|c|c|c}
\hline Resistance & Voltage & Value & $\begin{array}{c}\text { Withstanding } \\
\text { Voltage }\end{array}$ & Power & characteristic \\
\hline$R 25$ & $120-125 \mathrm{~V}$ & $100 \Omega-10 \mathrm{~K} \Omega$ & good & small & $\begin{array}{c}\text { Small slipstream current } \\
\text { at the start }\end{array}$ \\
\hline$R 25$ & $6-24 \mathrm{~V}$ & $0.5 \Omega-5 \Omega$ & bad & big & $\begin{array}{c}\text { Big slipstream current at } \\
\text { the start }\end{array}$ \\
\hline
\end{tabular}

1Resistance at room temperature is R25。Voltage: 120-125V. The R25 generally take $100 \Omega-10 \mathrm{~K} \Omega$.

2Curie temperature Tc should be moderate. Under certain conditions, the power consumption of the electric heating products can be improved by increasing the Tc.

3The temperature coefficient of resistance aT should be large, usually aT $\geq 14$.

(4)Appearance is smooth that the thickness tolerances must be strictly controlled within $\pm 0.2 \mathrm{~mm}^{[3]}$. 


\subsection{Structure}

The innovation of multi-functional shoe cabinet is the totally new structural arrangement. As shown in Figure 3, breaking the horizontal arrangement of common shoe cabinet while designing structure, and hanging shoes in the shoe cabinet through the rotating rack, which makes easy to store and take out. Jointing the shoes sole and sole in the vertical shoe ark, which greatly increase the space efficiency of shoe cabinet. The rotary structure and hanging frame of multi-functional are shown in Figure 4.

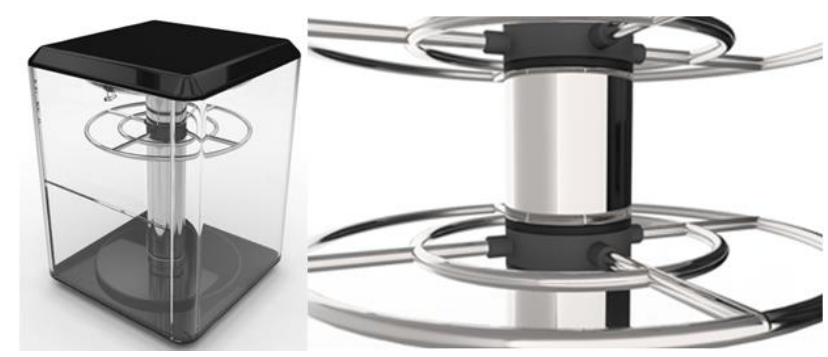
Figure 3. Rotary Structure of
Shoe Cabinet

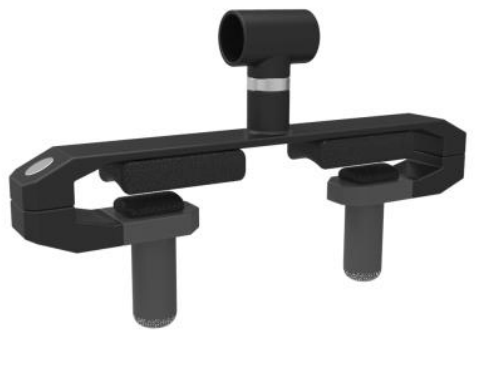

Figure 4. Hanging Frame of shoe Cabinet

In order to make the multi-functional shoe cabinet look united and simple, there are no decorations and extra parts outside. The opening and closing manner of the cabinet door will adopt rotation operation. The "bounce self-locking device" will be installed on both sides. Looking the shoe cabinet from outside, there is no handle on the door. So if the user wants to open the door, he just need to push the side of the door and then loosen, the door will open automatically. It is the same way in closing the door, pushing the door softly and it locking itself.

\section{Material and Technôlogy}

\subsection{Material}

Material selection not only has great influence on the internal and external appearance of the product, but also affects the use function and the overall aesthetic feeling of the product. Not only the inherent properties of the material should be considered, but also the organic contact between the material and people, the environment should be.

According to the requirements of the function, structure and appearance design of multi-functional shoecabinet, the materials used are as follows:

The external body shoe cabinet adopts PC HCG2520FR (Polycarbonate plastic).

The main material used is PC polycarbonate plastic。 PC polycarbonate plastic is a common thermoplastic, which plays an important role in daily life. Polycarbonate plastic has high temperature resistance, wear resistance, long life, non-toxic tasteless, and its biggest feature is its own impact resistance. Polycarbonate plastic can make fine and complex parts structure for various purposes. The performance parameters of HCG2520FR PC (polycarbonate plastic) at $23^{\circ} \mathrm{C}$ are shown in Table 3. 
Table 3. Performance Parameters of PC HCG2520FR at $23^{\circ} \mathrm{C}$

\begin{tabular}{c|c|c|c|c|c|c|c|c}
\hline $\begin{array}{c}\text { Basic } \\
\begin{array}{c}\text { performan } \\
\text { ce }\end{array}\end{array}$ & \multicolumn{3}{c|}{ Mechanical properties } & \multicolumn{2}{c|}{ Electrical properties } & \multicolumn{2}{c}{ Thermal properties } \\
\hline $\begin{array}{c}\text { Density } \\
\left(\mathrm{g} / \mathrm{cm}^{3}\right)\end{array}$ & $\begin{array}{c}\text { Tensile } \\
\text { strength } \\
\left(\mathrm{K} \mathrm{g} / \mathrm{cm}^{2)}\right.\end{array}$ & $\begin{array}{c}\text { Bending } \\
\text { strength } \\
\left(\mathrm{Kg} / \mathrm{cm}^{2)}\right.\end{array}$ & $\begin{array}{c}\text { Bending } \\
\text { Modulus } \\
\left(\mathrm{Kg} / \mathrm{cm}^{2)}\right.\end{array}$ & $\begin{array}{c}\text { Rockwell } \\
\text { hardness } \\
(\mathrm{R} \text { scale })\end{array}$ & $\begin{array}{c}\text { Dielectric } \\
\text { strength } \\
(\mathrm{KV} / \mathrm{mm})\end{array}$ & $\begin{array}{c}\text { Volume } \\
\text { resistivity } \\
\left(\Omega^{*} \mathrm{~cm}\right)\end{array}$ & $\begin{array}{c}\text { Flame } \\
\text { retardancy } \\
(\mathrm{CLASS})\end{array}$ & $\begin{array}{c}\text { Heat } \\
\text { distortion } \\
\text { temperat } \\
\text { ure }\left({ }^{\circ} \mathrm{C}\right)\end{array}$ \\
\hline 1.35 & 850 & 1500 & 55000 & 122 & 30 & $10^{16}$ & $\mathrm{~V}-0$ & 142 \\
\hline
\end{tabular}

The hanging frame inside the shoe ark uses 5083 Aluminum Alloy material.

Aluminum alloy is one of the most widely used non-ferrous metal structural materials in the industry. It has low density, high strength, which is close to or more than highquality steel, and good plasticity. As a result, it can be processed into a variety of profiles. It is widely used in the industry because of excellent electrical conductivity, thermal conductivity and resistance corrosion resistance, as well as light texture, high strength, being easily processed and tolerance stamping. According to the research demand, racks inside the shoe cabinet is made of 5052 aluminum alloy, which is $\mathrm{AV}-\mathrm{Mg}$ alloy aluminum alloy and widely used as a rust-proof aluminum alloy ${ }^{[4]}$. The alloy has high strength, especially high anti-fatigue strength, ductility and corros on resistance. Technical parameters and the chemical compositiôn of 5052 aluminum alloy are given in Table 4, Table 5 and Table 6.

Table 4. The Typical Mechanical Properties of 5052 Aluminum Alloy

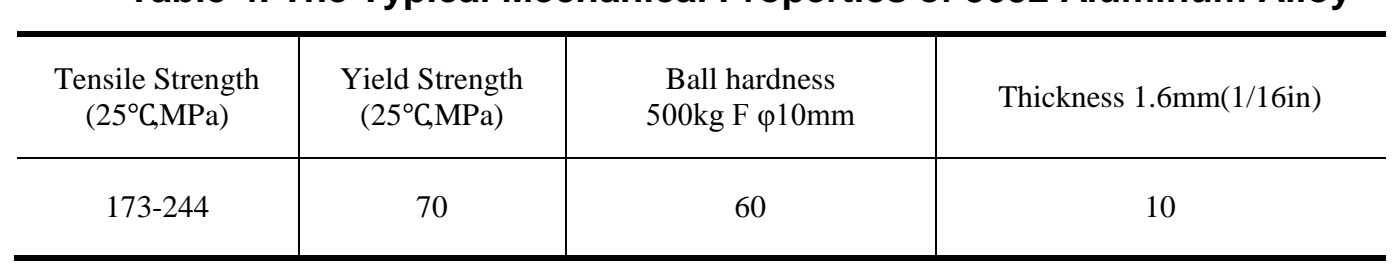

Table 5. The Typical Physical Properties of 5052 Aluminum Alloy

\begin{tabular}{c|c|c|c|c}
\hline $\begin{array}{c}\text { Thermal } \\
\text { conductivity } \\
\mathrm{W} /(\mathrm{m} . \mathrm{K})\end{array}$ & $\begin{array}{r}\text { Meleng } \\
\text { range }\left({ }^{\circ} \mathrm{C}\right)\end{array}$ & $\begin{array}{c}\text { Electrical conductivity } \\
20^{\circ} \mathrm{C}\left(68^{\circ} \mathrm{F}\right) \% \mathrm{IACS}\end{array}$ & $\begin{array}{c}\text { Resistivity } \\
20^{\circ} \mathrm{C} \mathrm{n} \Omega . \mathrm{m}\end{array}$ & $\begin{array}{c}\text { Density } \\
\left(20^{\circ} \mathrm{C}\right)\left(\mathrm{g} / \mathrm{cm}^{3}\right)\end{array}$ \\
\hline 117 & $570-640$ & 35 & 49.3 & 2.68 \\
\hline
\end{tabular}

Table 6. The Chemical Composition Limit of 5052 Aluminum Alloy

\begin{tabular}{|c|c|c|c|c|c|c|}
\hline $\mathrm{Fe}$ & $\mathrm{Cu}$ & $\mathrm{Mn}$ & $\mathrm{Mg}$ & $\mathrm{Cr}$ & $\mathrm{Zn}$ & $\mathrm{Si}$ \\
\hline 0.40 & 0.10 & 0.10 & $2.2-2.8$ & $0.15-0.35$ & 0.10 & 0.25 \\
\hline
\end{tabular}




\subsection{Crafts}

Different materials have different processing technology. The processing of PC plastic material, which is uesed by the outside of multi-functional shoe cabinet is simpler.It can use injection molding process, and as is shown in Figure 5. The first step of injection molding is adding the granular or powdery raw materials to the hopper of the injection molding machine, and then the material is heated and melted into fluid. Driven by the screw or the piston of the injection machine, the liquid material is injected into the mold cavity through the nozzle and mold casting system, and eventually hardened and shaped in the mold cavity ${ }^{[5]}$.

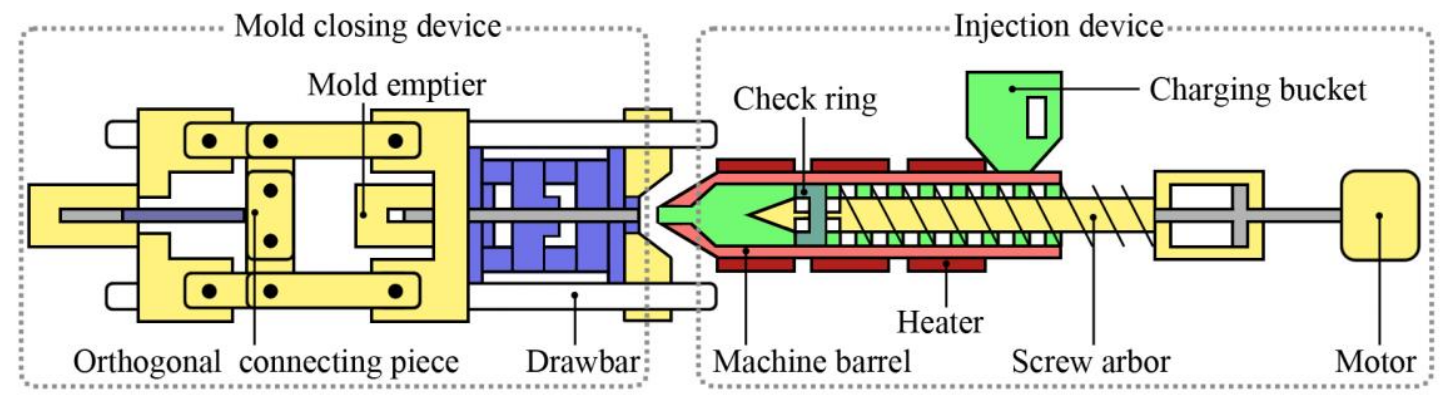

Figure 5. Injection Molding

The inside holder of multi-functional shoe cabinet adopts 5052 aluminum alloy. Cutting aluminum alloy material according to the size of the product, the curved surface can be processed by rolling or extrusion way. After processing the finished product, the surface treatment of the finished product is carried out. PTC heating element sections are directly processed in accordance with appropriate design drawings, and assembly to meet the structure requirements, and finally made of the finished products ${ }^{[6]}$.

\section{Colour Design}

Color is a kind of comprehenstve phenomenon involving light, object and vision. Color is the result of the light effects on human vision and brain. The color of the product plays a very important role in product design. When people feel the product, color will be noticed firstly, and ther the shape of the object and other factors will be. The charm of color plays an important role, affecting people's spiritual feeling ${ }^{[7]}$. Only if the color fits people's life style andaesthetic taste can it make people feel comfortable and beautiful. Each color has its, own characteristics, the relationship of commonly used color and psychological feelings are shown in table $7^{[8]}$.

\begin{tabular}{c|l} 
& Table 7. Relationship between Color and Mental Perception \\
\hline yellow & Yellow is the color of extremely lightness, has the effect of warning \\
\hline green & Green gives a fresh, peaceful feeling, used to show growth, life, safety \\
\hline blur & $\begin{array}{l}\text { Black gives a noble, stable, scientific and technological image, said the weight, hard, male, } \\
\text { industrial information }\end{array}$ \\
\hline black & $\begin{array}{l}\text { Black gives a noble, stable, scientific and technological image, said the weight, hard, male, } \\
\text { industrial information }\end{array}$ \\
\hline white & White gives a pure, noble feeling, people used to say that clean, cold and other information \\
\hline gray & Gray with a soft, elegant image, gray is always the main color of the popular \\
\hline
\end{tabular}


Different colors give people different psychological feelings. Multi-functional shoe cabinet applies clean and noble white color as the main tone. Effect as shown in Figure 6.

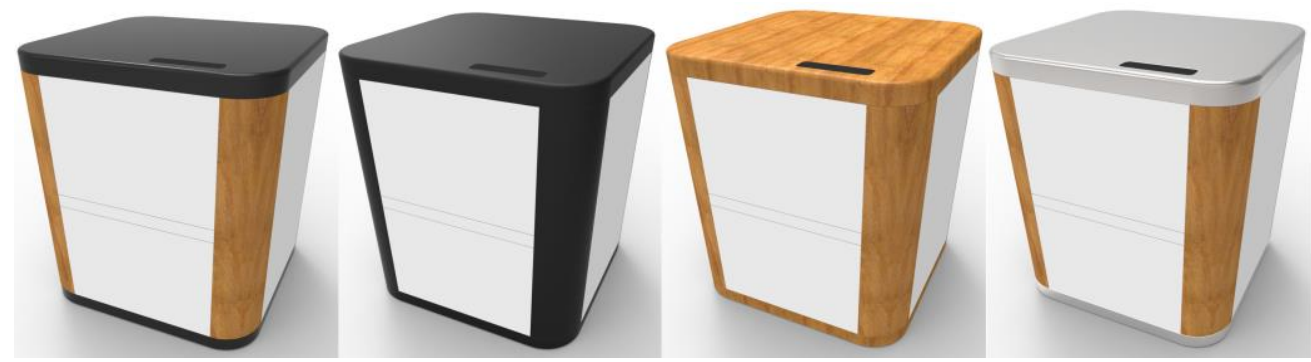

Figure 6. Different Colors of Share Refrigerator

\section{Man-Machine Relationship}

Ergonomics is a young science, using physiology, psychology and medicine and other relevant scientific knowledge, and researching the relations of machine system and human, in order to improve the overall system efficiency of the emerging edge of science. In daily life, each of us are contacting constantly with side items. When we use these items, things and people produce a kind of interactive relationship, which is knøwn as man-machine relationship. When a person is in a certain environment, theman-machine relationship is the relationship between man and the enyiromment ${ }^{[9]}$.

The man-machine system of new shoe cabinet is mainly composed of man and shoe cabinet. But this the shoe cabinet is generally used when people stand and bow over, so the design of multi-functional shoe-cabinet should be suitable for the operator's height, the height of shoe cabinet depends on whether the operator's finger can touch the shoe cabinet when bending. It is too high, too low will cause shoulder fatigue, back pain. The operator in the stand and bend over operation of man-machine relationship is shown in Figure 7.
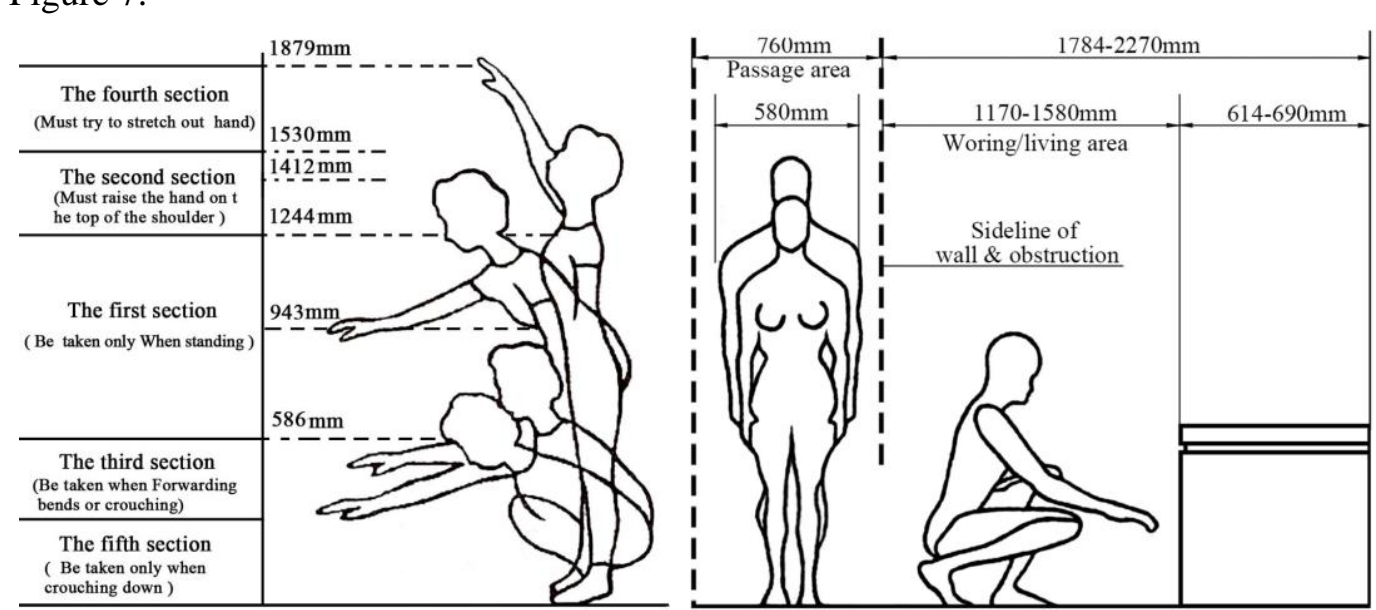

Figure 7. Man-Machine Relationship of People Operating

Multi-functional shoe cabinet fully consider the ergonomics factors in the design, elegant fashion design, lines full of vitality, reasonable man-machine relationship to meet the people's practical and aesthetic requirements. Multi-functional shoe cabinet's appearance design meets user's use, the size is suit to people using normal requirements, the size as shown in Figure 8.The final result of multi-functional shoe cabinet is shown as Figure 9. 


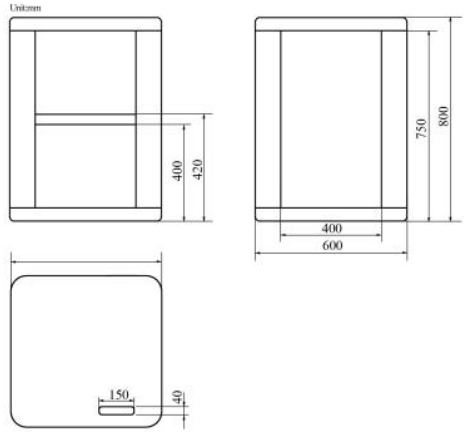

Figure 8. Sizes of Multi- Functional Shoe Cabinet

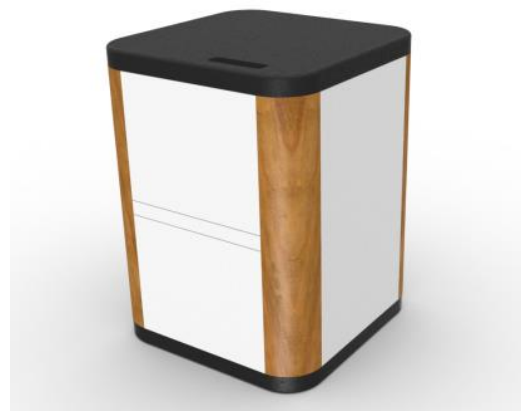

Figure 9. Final Result Picture of Product

\section{Conclusion}

The innovative design of multi-functional shoe cabinet discards the traditional mode of conventional design and introduce the sterilization, disinfection and drying' (ideas into the design. What's more, it no longer adheres to the simple storage function and changes the sole and old function of existing shoe cabinets in the market. Shoe cabinet integration has been greatly improved, which is also the development trend of nodern products. Breaking the original design of straight edge and right angle it is designed in a combination of organic and flat surfaces. This makes the multi-functional shoe cabinet look more vivid and beautiful. Multi-functional shoe cabinefis mainly designed to satisfy people's requirements of shoes storage, disinfection and drying. Meanwhile, it is aimed at making users feel comfortable and pleasure in daily life. The innovative design of multifunctional shoe cabinet is not only solyng the techmical problems such as materials choices, component matching and processing technology, but also saving problems of industrial design disciplines like product appearance, color matching and ergonomics principle. The multi-functional shoe cabinet makes users store shoes as well as enjoy better life, and it also provides a new life style for the future people.

\section{Acknowledgements}

The researeh is supported by National Natural Science Foundation of China (Grant No. E51505109), Natural Science Foundation of Heilongjiang Province of China (Grant No. E201440), Hellongjiang Province Education Bureau Project (Grant No. 12541146), Heilongjiang Postdoctorar Grant (Grant No.LBH-Z15102).

\section{References}

[1] Chujinvu Ozone technology and application.[M].Beijing:Chemical Industry Publishing press, 2003:88.

[2] Liao Hongbín. Development trend of electromagnetic oven products and technologies[J]. Household appliances, 2008,(11):50 52.

[3] Shiyaojun,Wunaiqun,Daiye.Research on Innovative Design of Portable Quick-drying Machine[J]. International Journal of Control and Automation,2015,8 (1): 149-156.

[41 Jiangxiangyun.Design materials and processing technology.[M].Beijing:Beijing institute of technology pres.2003:18 25 .

[5] Xuecheng Qi, Fei Wen Kai. Industrial design basis[M]. Nanjing:Southeast University press. 2004:1 103.

[6] Christopher Grimm.A Case Study System C-Based Design of an Industrial Exposure Control Unit. Springer US,2004:119 260.

[7] Shiyaojun,Wunaiqun,Daiye.Research on Innovative Design of Mobile Cooking Table[J]. International Journal of Smart Home,2015,9 (11): 47-54.

[8] DAI Ye, LAI Yinan, ZHANG Yuan, et al. Study on Rapid Simplification of CAD Model based on Rules and Fuzzy Judgment[J]. Journal of Harbin University of Science and Technology, 2013, 18(4):3741.Zhao Guozhi. Color composition[M].Shenyang: Liaoning Fine Arts Publishing press, 2003:31.

[9] Ding Yulan. Man machine engineering. Beijing Institute of Technology press, 2005:90 172 . 